\title{
Green bonds issuance: insights in low- and middle-income countries
}

\author{
Ursule Yvanna Otek Ntsama ${ }^{1 *}$, Chen Yan ${ }^{2}$, Alireza Nasiri ${ }^{3}$ and Abdel Hamid Mbouombouo Mboungam ${ }^{4}$
}

\begin{abstract}
Former reports of Environmental, Social and Governance (ESG) tended to focus on the equity side of investing, and today green bonds also offer and introduce sustainability factors. This paper is about the relevance, potential benefits and key arguments for countries with low-and middle-incomes where financial markets are not comparable with those in developed countries. We begin by stating clearly the relevance of a green economy transformation, highlight the development challenges they face and talk about how a green economy approach can help to solve these challenges. Then an outline of the progress that has been made in this panel, and the economic and social benefits that a green economy can potentially offer to Low- and Middle-Income countries (LMIC's) will be underlined. Finally, we will make recommendations on the range of potential areas for intervention.
\end{abstract}

Keywords: LMIC's, Green bonds, ESG, Sustainability investment

\section{Introduction}

The global warming has increased per decade since 1880 (National Centers for Environmental Information, 2019) and has brought many concerns throughout economists and market participants. The part of the globe that has warmed since 1880 represents $98 \%$; this suggests new risks that affect the economy. The first to merge global warming into endogenous growth models was Nordhaus (1990); but it is with the Stern review, (Stern, 2006) drawn up at the request of the British government, that economic theory really enters the debates on climate policy. The investments required to mitigate these disruptions are massive. Knowing that public investment cannot be a solution on its own, private capital will be essential to finance the green economy and the innovations that must accompany it. In response to this need of liquidity, the famous Green Bonds (considered as viable alternative to traditional financing mechanisms) have been launched to finance projects that respect certain environmental criteria.

\footnotetext{
* Correspondence: yvannaursule@yahoo.fr

${ }^{1}$ School of Accounting, Dongbei University of Finance and Economics, No.

217 JianShan St., Shahekou District, Dalian 116025, China

Full list of author information is available at the end of the article
}

Around 1970, Socially Responsible Investing (SRI) was a curiosity and a niche market. It has since become a global movement and has entered the vocabulary and consciousness of the world of finance (Sparkes, 2002). The first green bond was issued in 2008 and was carried out in Europe. It is especially since the 2015 Paris Climate Agreement that the green bond market has grown remarkably, despite the lack of a precise definition of the object financed by these bonds that would be recognised by all players at the international level. Globally, green bond issues hit a record of more than $\$ 250$ billion in 2019 (Climate Bonds Initiative, C., 2020). Despite the current crisis related to Covid-19, the trend for this product, as well as for the bonds of the same family such as social and sustainable obligations, remains that of an increasingly large and diverse growth. Green bonds are among the options available for private sector companies and public institutions committed to support climate and environmentally friendly investments. In 2019, the financial performance of the green bond market was supported by the overall downward movement in rates: the most followed index by managers, the Bloomberg Barclays MSCI Global Green Bond Index, gained 6.50\% over the year, after a year 2018 in the red $(-0.72 \%)$. According to figures compiled by the Climate Bonds 
Initiative (Climate Bonds Initiative, C., 2020), green bond issues broke records in 2019: $\$ 255$ billion (231 billion Euros) of new securities added to the market, up from $\$ 167$ billion in 2018. And the trend is expected to continue in 2020, with $\$ 350$ billion to $\$ 400$ billion in emissions expected (Filkova \& Almeida, 2019).

For the past 4 years, in the wake of the Paris Agreement, 2015, green bond markets expanded strongly. They differ from conventional bonds by the expected environmental benefit of the funded project. However, it falls short of the financing needs of the ecological transition. In addition, the absence of a precise legal definition of financing objects, create a risk of greenwashing for the issuer and increase the cost of information on the nature of the project for the investor.

The growth prospects of the Green Bonds market are encouraging with many government initiatives in lowand middle-income countries to support the development of this market. The need to standardize the eligibility criteria for Green Bonds is certainly one of the biggest challenges facing this still-recent market. Despite the multiple difficulties faced by low-and middle-income countries (poverty, political conflicts, and ecosystem degradation), with Africa being the most vulnerable one to climate-change policies, implementation of green capital continues to make its way. Africa's green bond issuance is $0.18 \%$ of its total market capitalization, compared to $0.4 \%$ in North America (US\& Canada), $1.9 \%$ in Eurozone, $0.89 \%$ in China (World Bank Group 2019). Therefore, the successful development of green bond markets entails considering several different factors.

It should be noted here that the focus will not be on African countries because of the relatively small size of African financial markets compared to other regions. As the Green, Social and Sustainability Bonds market is a growing market, private investors are more likely to invest in global capital markets, where they have a better social, economic and political context control. At the global level despite the recent development of finance, countries such as France, Sweden, Switzerland, China, and some states of the United States of America, are leaders in the field with the establishment of a regulatory framework and also the issuance of several green and sustainable bonds. Climate finance in 2017/2018 has increased by $25 \%$ over previous years, thanks to the rapid growth of installed renewable energy capacity in China and India, the growing commitment to better land use and energy efficiency in many parts of the world. By region, East Asia and the Pacific remains the top destination for climate finance (this region received $\$ 238$ billion a year, or $41 \%$ of the climate finance tracked. A trend mainly due to China which is the largest provider and the first destination of climate finance, for several years). The fastest growth in climate finance has been observed in Oceania, the Middle East and North Africa. The climate funding received by Oceania in 2017/2018 is equivalent to $165 \%$ of the amounts received in 2015/ 2016. There is also a 78\% growth in North Africa over this period.

The paper is a summary of recent literature, aiming to generalize relevant academic researches and seeks to provide an introduction to green bonds for new scholars. Secondly, it attempts to give a platform for further green finance research by delineating the major financial, practical and political concerns with green bonds in low-and middle-income countries. Finally, it aims to enlarge our knowledge of the green bond market by putting critical research agendas into direct conversation. The paper concludes by calling for more explicit analysis of green bonds in low-and middle-income countries. By learning from the current status, we hope to form a proper understanding of the conceptual issues, identify the development trends and provide useful guidance on future research directions in this important and developing subject.

\section{Methodology}

The method used in this paper is a systematic analysis approach. A systematic review is a critical synthesis of research evidence, which involves analysis of all available and relevant evidence in a systematic, objective and robust manner (Fig. 1).

As well as mathematics education, it can be applied to numerous disciplines (Schwarz, 2015) and can be used both to develop theories, describe social phenomena or test hypotheses (Hopf, 2016). For this purpose, a special focus should be paid on the formation of categories and codes that are important for an effective research (Kuckartz, 2019).

\section{Literature review \\ Socially responsible investing}

The research on SRI has increased over the last decade. From 1900 to 2017, a total of 634 SRI articles has been recorded (Widyawati, 2019). Socially Responsible Investment is a hybrid form of investing that covers important criteria (Environmental, Social or Governance) grouped under the acronym ESG (Avetisyan \& Hockerts, 2017; Friede, 2019) aiming to achieve sustainable development goals (PRI, 2017). Responsible investing is done in two ways: the first is to eliminate companies whose balance sheets are not considered to be responsible (this approach is the main one in Europe). The second approach is to rate companies on ESG criteria and invest more in companies with the best ESG profile Without completely excluding less responsible companies (this approach is the main one in the USA). However, the concept of SRI is extremely complex and individualize from one 


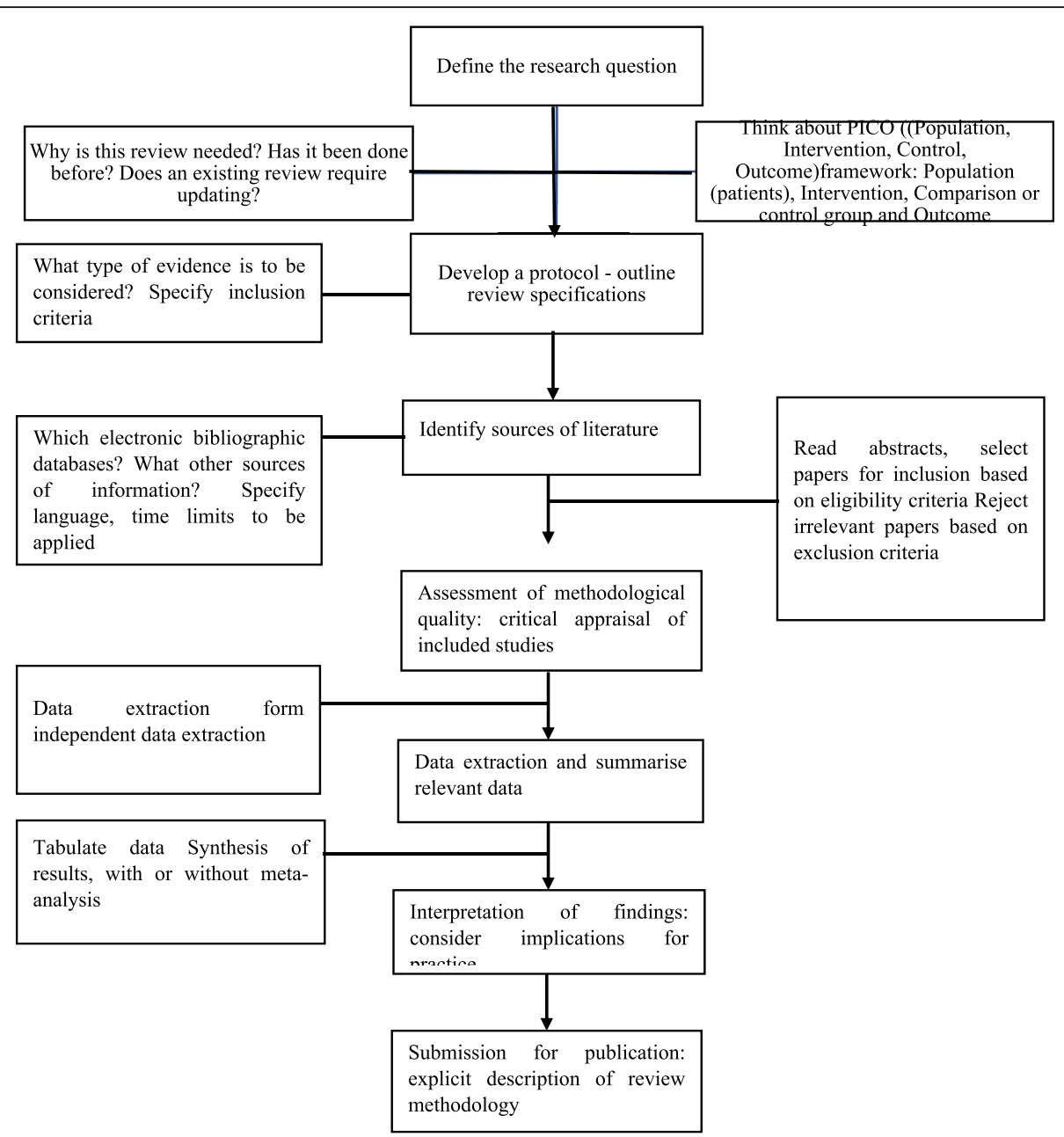

Fig. 1 Research design for a systematic literature review

investor to another (Sandberg et al., 2009; Juravle \& Lewis, 2008).

\section{From sustainable finance to green finance}

The term sustainability is "a capacity to support some entity, outcome, or process over time" (Jenkins, 2009) and carrying out activities that do not exhaust the resources on which that capacity depends.

Sustainable Finance refers to financial practices that take into account extra-financial reporting including social, environmental, societal and governance information on corporate activity. It includes Socially Responsible Investing (SRI), which has had its own label since August 2016, and has served to companies that met the ESG (Environmental, Social and Governance) criteria in a sustainable way. Indeed here, the concept of environment and sustainable development is present, but also social criteria (such as respect for gender parity) or governance criteria (such as transparency in executive pay).
Green finance covers all services offered in financial markets to invest in initiatives to reduce the impact of human activities on the environment or to offer social, economic and environmental benefits. The main tool of green finance remains green bonds (Table 1).

\section{Overview of green bonds markets Typology of green bonds}

Bonds can be used to finance or refinance a variety of projects and activities, such as infrastructure, power plants or maintaining ongoing operations (Weber \& Feltmate, 2016). A green bond is a debt security issued by a government entity, a multilateral institution, or a corporation to raise capital from investors for a project that contributes to a low-carbon, climate-resilient economy (Inderst et al., 2012). Green bonds are fixed-income instruments with proceeds earmarked exclusively for new and existing projects that have environmental benefits (Syzdykov \& Masse, 2019). The term 'green bonds' refers to bonds whose proceeds are used to finance 
Table 1 Overview of reports on Green Finance

\begin{tabular}{ll}
$\begin{array}{l}\text { Authors/publication and } \\
\text { year }\end{array}$ & Meaning and understanding of Green Finance \\
$\begin{array}{ll}\text { (Höhne, Khosla, Fekete, \& } \\
\text { Gilbert, 2012) }\end{array}$ & $\begin{array}{l}\text { "Green finance is a broad term that can refer to financial investments flowing into sustainable development projects } \\
\text { and initiatives, environmental products, policies that encourage the development of a more sustainable economy, } \\
\text { and to a wider range of environmental objectives." }\end{array}$ \\
$\begin{array}{ll}\text { (Zadek \& Flynn, 2013) } & \text { "Green finance is often used interchangeably with green investment. However, in practice, green finance is a wider } \\
\text { lens including more than investments as defined by Bloomberg New Energy Finance and others. Most important is } \\
\text { that it includes operational costs of green investments not included under the definition of green investment. Most } \\
\text { obviously, it would include costs such as project preparation and land acquisition costs, both of which are not just } \\
\text { significant but can pose distinct financing challenges." } \\
\text { "For the banking sector, green finance is defined as financial products and services, under the consideration of }\end{array}$ \\
$\begin{array}{l}\text { (PricewaterhouseCoopers, } \\
\text { 2013) } \\
\text { environmental factors throughout the lending decision making, ex-post monitoring and risk management processes, } \\
\text { dustries and businesses." } \\
\text { "According to our definition, "Green Finance" comprises all forms of investment or lending that take into account } \\
\text { environmental impact and enhance environmental sustainability. A key element of Green Finance is sustainable } \\
\text { investment and banking, where investment and lending decisions are taken on the basis of environmental screening } \\
\text { and risk assessment to meet environmental sustainability standards." }\end{array}$ \\
\hline
\end{tabular}

environmentally-friendly projects (Mercer, 2015) such as renewables, water and energy efficiency, bioenergy, and low carbon transports (Campiglio, 2016). They not only encompass financial obligations but also incorporate environmental benefits claimed by the green bond issuer (Bartels et al., 2016). Given the ESG shortfalls and other considerable factors, investors are offered a reasonable way to positively support sustainability while investing in a relatively low risk / low yield instrument (Kidney et al., 2012).

There are six types of green bonds (Table 2) referred as followed:

\section{Development of green bonds markets}

The first green bond was issued in 2007 by the European Investment Bank (EIB), which was followed in 2008 by the International Bank for Reconstruction and Development (IBRD) (Coston et al., 2014; Stoian \& Iorgulescu, 2019). The green bond market grew from $\$ 1.5$ billion in
2007 to $\$ 389$ billion in 2018 (CBI 2018c, 2018). Since its launch, the Green Bond has been a resounding success.

Far from their original containment to energy and water management, they are now linked to land use, waste management or sustainable transport. They also attract more exotic finances; the first Islamic Green Bond was issued in July 2017 in Malaysia. In 2015 some of the countries listed in this study joined the green bond market such as: Brazil, Denmark, Estonia, China, India, Latvia, and Mexico, contributing to a total annual issuance of $\$ 41.8 \mathrm{bn}$. According to Kreivi (2017), Director and Head of Capital Markets Department, European Investment Bank, the green bonds' principles are embedded into four components.

But today the Green Bonds market is at a critical stage in its development. Too unregulated, sometimes opaque, often subject to market imperfections, green bonds represent no more than $5 \%$ of bond issues. Some of these challenges are related to ensuring that the use of

Table 2 Typology of Green Bonds

\begin{tabular}{|c|c|c|}
\hline Green Bond Type & Attribute & Debt recourse \\
\hline $\begin{array}{l}\text { Use-of-Proceeds } \\
\text { Bond }\end{array}$ & $\begin{array}{l}\text { Proceeds raised by bond sale are earmarked for } \\
\text { green projects in the issuer's portfolio. }\end{array}$ & Recourse to the issuer. Entire balance sheet \\
\hline $\begin{array}{l}\text { Use-of-Proceeds } \\
\text { Revenue Bond or } \\
\text { ABS }\end{array}$ & $\begin{array}{l}\text { Proceeds raised by bond sale are earmarked for } \\
\text { or refinances green projects }\end{array}$ & Recourse is limited to an issuer's pledged revenue streams. \\
\hline Project Bond & $\begin{array}{l}\text { Proceeds raised by bond sale are earmarked for } \\
\text { a specific project. }\end{array}$ & Recourse is restrained to the project's assets and balance sheet \\
\hline $\begin{array}{l}\text { Securitisation (ABS) } \\
\text { Bond }\end{array}$ & $\begin{array}{l}\text { Proceeds raised by bond sale are pooled are } \\
\text { earmarked for green projects }\end{array}$ & Recourse is to a group of projects that have been grouped together \\
\hline Covered Bond & $\begin{array}{l}\text { Proceeds raised by bond sale are earmarked for } \\
\text { eligible projects included in the covered pool }\end{array}$ & $\begin{array}{l}\text { Recourse either to the issuing entity or to an affiliated group to which the } \\
\text { issuing entity belongs and to a pool of collateral that is separate from the } \\
\text { issuer's other assets }\end{array}$ \\
\hline Loan & $\begin{array}{l}\text { Proceeds raised by bond sale are earmarked for } \\
\text { eligible projects or secured on eligible assets }\end{array}$ & $\begin{array}{l}\text { Recourse is full to the borrower in the case of unsecured loans. } \\
\text { Recourse to the collateral in the case of secured loans }\end{array}$ \\
\hline
\end{tabular}


proceeds from green bonds is strictly guided by sustainability principles to guard against "green washing". In 2019 emerging market green bond issuance rose from $21 \%$ to $\$ 52 \mathrm{bn}$ with China the largest issuer (AmundiIFC, 2020). But despite this significant growth, those countries are facing some challenges such as political instabilities, the quality and availability of information and green label assets.

\section{The current state of low-and middle-income countries' (LMIC's) green bonds markets}

Markets in low- and middle-income countries are the most exposed regions to climate change risks, but they face an unprecedented challenge to decarbonize their economies while maintaining a sustainable economic development trajectory. The first green bond issuance from LMIC's took place in 2012 in South Africa, but global growth in these types of bonds is driven by China, with the East Asia and Pacific region accounting for $81 \%$ of the market. In 2014, they amounted from $\$ 4.5$ billion; a 10 -fold increase in one year ( $\$ 42$ billion in 2015) to $\$ 81$ billion in 2016. While green bonds accounted for only $1 \%$ of bond issues at the beginning of 2017, growing investor interest and the entry of large bond issuers from the states into this market (previously held by large companies only) should be a game changer (Filkova, 2018).

Figure 2 shows the share of dominant emerging markets climate-aligned bond issuers from 2012 to 2019. It suggests that China and India dominate the market, and have strengthened growth in this market in 2017. In the first quarter of 2017, the global contribution of emerging markets was $15 \%$, whereas in the first quarter of 2018 , this contribution doubled and was 32 of global firstquarter issuance (Filkova, 2018).

\section{Barriers to the green bond market in LMIC's}

The limits and inconsistency of green bond certification schemes are recognised by all, both by states and international organisations and by market participants.
Today, both green bond issuers and investors face the challenge of overcoming the current market turbulence. The global green bond market, which has now exceeded $\$ 700$ billion in outstanding issues, is booming rapidly. This market is an essential source of financing for projects with positive environmental effects, both in developed and low countries. The main obstacle faced by portfolio managers investing in LMIC's markets is that ESG standards can be very different from those in Western countries.

However, key challenges are being met to further help the expansion of these green bond markets:

\section{- Underdeveloped capital markets with insufficient} liquidity and high transaction costs: Promoting green products and greening financial markets are not without challenges for the stock market. These guidelines address a number of specific challenges, obstacles and barriers, including: insufficient supply to meet investor demand; lack of liquidity in green products and taxonomy. By facilitating the issuance, identification and investment of sustainable financial securities, stock exchanges can catalyse the transition of their financial centres while ensuring the sustainability of their activities. In addition, many studies show that investor sentiment may drive decisions (De Long et al., 1990; Cen \& Liyan-Yang, 2013) for instance, weather conditions (Hirshleifer \& Shumway, 2003; Saunders, 1993).

- The quality and availability of information to identify, measure and track green investments: Investors often also seek information about the overall ESG performance of green bond issuers. However, the lack of a generally accepted taxonomy makes it almost impossible to investors and stakeholders to receive complete and reliable information (Filkova \& Almeida, 2019).

- Institutional barriers: the smallest size and insufficient technical capacity of the financial

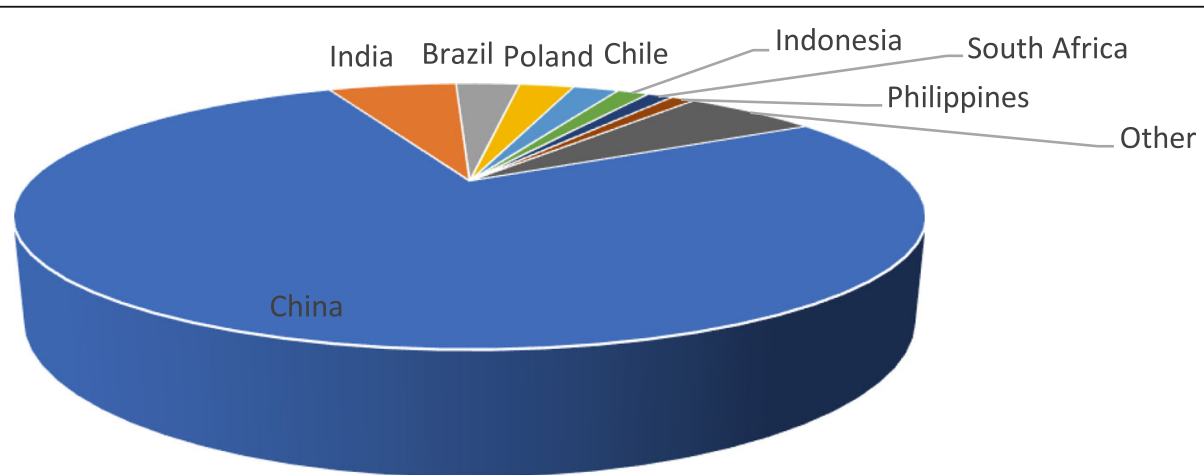

Fig. 2 Cumulative LMIC's Green Bond Issuance from 2012 to 2019 (\%). Source: International Financial Corporation, Global Macro \& Market Research, Bloomberg, Environmental Finance, Climate Bonds Initiative (2019) https://www.climatebonds.net/files/reports/2019_annual_highlights-final.pdf 
institutions are some important barriers (Banga, 2019). Indeed, a minimum size of green bond should be reached to ensure liquidity support and tender bonds (Banga, 2019). In some low-income countries profit seeking lead banks to face difficulties in implementing the basics of sustainable finance. There is an extreme need to enhance coöperation within financial institutions so as to develop a sustainable finance roadmap.

\section{ESG management strengthens its position: what is the contribution of ESG in the bond universe of low- and middle-income countries?}

The 1980s and 1990s were characterized by the creation of several Socially Responsible Investing funds and the launch of the first responsible index with the creation of the Domini Social Index, composed of 400 large US capitalizations selected according to social and environmental criteria. Beginning in the late 1990s, socially responsible investors began to include risk and return considerations in their investment choices through the use of techniques that maximize financial return. This growing interest in the performance of responsible investors led to the UNEP (United Nations Environment Programme) financial initiative in 2003, where a working group on environmental, social and governance (ESG) issues related to financial assets. Environmental, social and governance (ESG) factors, which have long been taken into account in developed economies, are rapidly becoming priority issues in LMIC's markets. Not surprisingly, over the past decade the MSCI Emerging Markets, which tracks companies that outperform ESG on their peers, outperformed with an annualized gross return of 6.98\% (compared to 3.73\%) (Rowe Price, 2019) (Fig. 3).

Since the beginning of the coronavirus crisis, some stocks have been able to cushion their fall in the stock market. With the coronavirus pandemic affecting every facet of life, emerging market economies have far less room for fiscal and monetary manoeuvring (AmundiIFC, 2020).
Policy recommendations for ESG management in LMIC's For LMIC's green bonds, the limited number of green bonds issuance and the relative lack of proxies, make it relatively difficult to measure the performance of the market (Amundi-IFC, 2020).

\section{What standards for responsible investing?}

To scale up with this issues, some market analysts are suggesting internationally recognized standards. Lack of standardization is a real headache for ESG investors. Indeed, standardization can result in robust frameworks for monitoring, reporting and assurance of the green bond proceeds that will enable new issuers to be attracted by the market opportunities. Unfortunately, a proliferation of standards could "severely slow down" the development of the green bond market. Because today, the lack of clear criteria of definition discourages some issuers from launching for fear of accusation of green washing. On the other hand, the development of overly restrictive standards could have the same deterrent effects. Green bonds are issued within a specific framework, usually the Green Bond Principles (GBP) of International Market Capital Association (2018). Other repositories are sometimes used, but they are generally established by supranational or state agencies. Most selfproclaimed "green" bonds are then given a second opinion by qualified agencies and auditors.

\section{Taxonomies}

As taxonomies are being developed, one issue that's arising is finding the right balance between. Taxonomies provide all market participants and consumers with a common understanding of qualifying activities, protects against green washing and provides the basis for further policy actions, including standards, labels, incentives and potential changes to prudential rules. Countries will need to determine what works best for their circumstances and how much to develop their own taxonomy or draw on others.

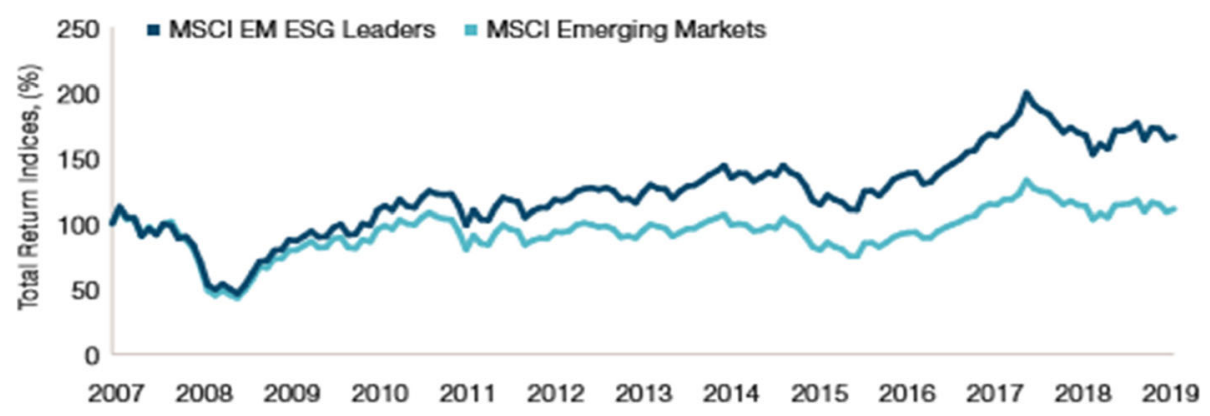

Fig. 3 Cumulative Gross Index Return (September 2007 to September 2019). Source: MSCl, data analysis (Rowe Price, 2019) 


\section{Building consensus}

In December 2019, the Climate Bond Initiative published the third version of its international standard to ensure compatibility with the new European standard for green bonds and the latest version of the Green Bond Principles by strengthening definitions of green bonds and information requirements. The Climate Bond Initiative's consensus-based standardization and strict taxonomy help pave the way for passive investments and the risk of greenwashing, in other words investments that look greener than they actually are.

\section{Lower costs and transparency}

Improved ESG data collection, processing and standardization allows index providers to codify ESG targets in benchmarks with high accuracy, rigor and transparency. Indeed, managers of actively managed green bond funds charge higher fees to cover research costs and analysts' salaries. On the other hand, the Exchange-Traded Funds rules-based approach that replicates indices would reduce costs for investors. All investors want to know where their money is going, especially when it comes to ESG investments such as green bonds. In the seeking of transparency, the appointment of mandatory or voluntary external reviewers (to certify alignment with Green Bond Principles, Green Loans Principles, and Climate Bond Standards) increased investors' confidence.

\section{Gradually implement sustainable finance and market globalization}

Market access is limited in developed countries; indeed, on one hand, to catch up with those countries, the establishment and development of an online learning platform for awareness and training would be an important asset (It could also involve re-rewards for banks, especially local ones, and businesses to encourage strong performance). On the other hand, the improvement of a local market access for an emerging class of global green investors is also a great asset (OECD, 2017).

In order to facilitate the understanding and participation of investors in the African green market, the authorities should first and foremost be receptive to innovation. Second, it is a gradual approach that should include a collaborative multi-party working group to develop guidelines, consultations with all market participants and consumers to develop a national plan, prepare a roadmap, set up a regulatory framework and launch the sector. This involves building an ecosystem for green capital markets, ensuring flexibility taking into account both financial aspects, and economic and environmental contexts. From 2007 to 2016 , only $6.5 \%$ of global green issuance flowed within low-income countries (Banga, 2019).

\section{Tax incentives to stimulate market growth}

Investors should check the so-called "greenwashing" (directing its actions towards green positioning), the impact on investment, pricing, risk/return trade-offs, and investment comparisons. In the same vein, it is a question of securing a pipeline of market-ready and investment-ready projects for these types of bonds. This requires good Interaction between public officials/private actors to increase climate finance for nationally determined contributions.

\section{Implications}

\section{Academic implications}

The goal of this paper was to explore emerging research trends of the impact of green bonds in low-and-middle income countries using a systematic approach. This article contributes to research on sustainable finance by elucidating the theoretical evolution of green bonds issuance research and its linkages with multiple economic, social, and governance factors. An understanding of the contributions of the most productive scholars and their research helps to build our work by choosing and following a line of inquiry. This study outlines several research propositions that can serve as a foundation for future research in the area of green bonds issuance.

\section{Managerial implications}

This study could benefit managers interested in adopting a proactive approach to understand which changes in strategies, services, and products are required to meet unprecedented demands and develop sustainable business practices. The propositions discussed above suggest that, credible standards should be widely applied to develop the market of green bonds in low-and middleincome countries, projects with long-term investments horizons, secure income streams and large capital costs.

\section{Conclusion}

Green bonds are an effective financing mechanism that benefits both issuers and investors, and can help mobilize private capital available in developed countries. Investors are increasingly taking environmental, social and governance factors into account along traditional financial risks. While investments have already been made, significant problems have arisen due to the lack of tools to assess natural resources and in the absence of a strong and universal standard capable of encouraging financial institutions, if not forcing them, to reduce their exposure to the risks associated with climate change. So far, in case of greenwashing, the lack of standardization of emission and monitoring methods are leading many investors to hesitate on the use of ESG criteria for lowand middle-income markets, fearing that this will limit potential opportunities or returns. 
This study is trying to gain perceptive insights into the area of sustainable finance research using systematic analysis, and used research scholar databases and institutional reports to collect data. The results suggest that on the contrary to developed countries, the institutional, financial, and political barriers are keeping the green market in low-and-middle income countries in an embryonic state. The results also suggest that measures should be taken to greening the bonds. In their process of greening the financial sector, governments should focus on pension funds and insurance companies; they should increase the level of private sector investment by applying tax liabilities, for example. On the other hand, central banks should harmonize standards to build investor confidence and ease decision-making. This will require the construction of a normative system that is readable and accepted by all. In order to increase the credibility of green bonds in low-and middle-income economies, standardization of reporting is needed in sectors where there is no certification system yet; furthermore, the practice of issuers making hypothetical self-proclaimed statements about green profits (with or without external advice/opinion) must evolve into a model that provides for certification of real profits according to effective and credible standards widely recognized by an accredited third party.

\section{Abbreviations}

EIB: European Investment Bank; ESG: Environmental, Social and Governance; GBP: Green Bonds Principles; IBRD: International Bank for Reconstruction and Development; LMIC: Low- and Middle-Income Country; MSCI: Morgan Stanley Capital International index; SRI: Socially Responsible Investing; UNEP: United Nations Environment Programme

\section{Acknowledgements \\ We confirm that the manuscript has been read and approved by all named authors and that there are no other persons who satisfied the criteria for authorship but are not listed. We further confirm that the order of authors listed in the manuscript has been approved by all of us. \\ We confirm that we have given due consideration to the protection of intellectual property associated with this work and that there are no impediments to publication, including the timing of publication, with respect to intellectual property. In so doing we confirm that we have followed the regulations of our institutions concerning intellectual proper We understand that the Corresponding Author is the sole contact for the Editorial process. He/she is responsible for communicating with the other authors about progress, submissions of revisions and final approval of proofs. We confirm that we have provided a current, correct email address which is accessible by the Corresponding Author.}

\section{Authors' contributions}

ON performed the historical and analysis of green bonds on the current sample. CY and AN supervised the work, MA revised the language and technical part of the paper. The author(s) read and approved the final manuscript.

\section{Funding}

Not applicable.

We wish to confirm that has been no significant financial support for this work that could have influenced its outcome.

Availability of data and materials

The datasets analysed during the current study are available in
- https://www.ifc.org/wps/wcm/connect/a64560ef-b074-4a53-8173-f678ccb4 f9cd/202005-EM-Green-Bonds-Report-2019.pdf?MOD=AJPERES\&CVID= n7Gtahg

- https://www.troweprice.com/content/dam/ide/articles/pdfs/2019/q4/inemerging-markets-does-it-pay-to-worry-about-esg-factors.pdf

\section{Competing interests}

Not applicable.

We wish to confirm that there are no known conflicts of interest associated with this publication.

\section{Author details}

${ }^{1}$ School of Accounting, Dongbei University of Finance and Economics, No. 217 JianShan St., Shahekou District, Dalian 116025, China. ${ }^{2}$ School of Accounting, Dongbei University of Finance and Economics, No. 217 JianShan St., Shahekou District, Dalian 116025, China. ${ }^{3}$ University of Tehran, Tehran, Iran. ${ }^{4}$ Northwestern Polytechnical University, 1 Dongxiang Road, Chang'an District, Xi'an 710129, Shaanxi, China.

Received: 29 September 2020 Accepted: 3 December 2020

Published online: 04 January 2021

\section{References}

Amundi-IFC (2020). Emerging market green bond report. World Bank Group 202005-EM-Green-Bonds-Report-2019.pdf (ifc.org).

Avetisyan, E., \& Hockerts, K. (2017). The consolidation of the ESG rating industry as an enactment of institutional retrogression. Business Strategy and the Environment, 316-330 https://doi.org/10.1002/bse.1919.

Banga, J. (2019). The green bond market: A potential source of climate finance for developing countries. Journal of Sustainable Finance and Investment, 9(1), 17-32 https://doi.org/10.1080/20430795.2018.1498617.

Bartels, W., Kurznack, L., Briaut, L., \& Krimphoff, J. (2016). Mainstreaming the green bond market: Pathways towards common standards. KPMG Advisory N. V.

Berensmann, K., Dafe, F., \& Lindenberg, N. (2018). Demystifying Green Bonds. In S. Boubaker, D. Cumming, \& D. E. Nguyen (Eds.), Research handbook of investing in the triple bottom line, (pp. 333-352).

Campiglio, E. (2016). Beyond carbon pricing: The role of banking and monetary policy in financing the transition to a low-carbon economy. Ecological Economics, 121, 220-230 https://doi.org/10.1016/j.ecolecon.2015.03.020.

CBI 2018c. (2018). Green bond pricing in the primary market H1 (Q1-Q2). Retrieved from https://www.climatebonds.net/files/reports/cbi_pricing_ h1_2018_01l.pdf

Cen, L., \& Liyan-Yang, H. (2013). Investor sentiment, disagreement, and the breadth return relationship. Management Science, 59, 1076-1091 https://doi. org/10.1287/mnsc.1120.1633.

Climate Bonds Initiative. (2018). Explaining green bonds. Retrieved from https:// www.climatebonds.net/market/explaining-green-bonds

Climate Bonds Initiative, C (2020). 2019 green bond market summary. CBI Retrieved from https://www.climatebonds.net/files/reports/2019_annual_ highlights-final.pdf.

Coston, E., et al. (2014). Next Season's green bond harvest : Innovations in green credit markets. Washington, D.C: World Bank Group.

De Long, J., Shleifer, A., Summers, L., \& Waldmann, R. (1990). Noise trader risk in financial markets. Journal of Political Economy, 98, 703-738 https://doi.org/10. 1086/261703.

Filkova, M. (2018). Bonds and climate change: State of the market 2018 report. Climate Bonds Initiative.

Filkova, M., \& Almeida, M. (2019). Climate bonds initiative, post-issuance reporting in the green bond market. Climate Bonds Initiative Retrieved from https:// www.climatebonds.net/files/reports/cbi_post-issuance-reporting_rev092019_ en_0.pdf.

Friede, G. (2019). Why don't we see more action? A metasynthesis of the investor impediments to integrate environmental, social, and governance factors. Business Strategy and the Environment. https://doi.org/10.1002/bse.2346.

Hens, L., et al. (2016). Financing the green transformation: How to make green finance work in Indonesia. Environment, Development and Sustainability, 18, 949-950 https://doi.org/10.1007/s10668-015-9750-y.

Hirshleifer, D., \& Shumway, T. (2003). Good day sunshine: Stock returns and the weather. The Journal of Finance, 58, 1009-1032 https://doi.org/10.1111/15406261.00556. 
Höhne, N., Khosla, S., Fekete, H., \& Gilbert, A. (2012). Mapping of green finance delivered by IDFC members in 2011. Retrieved from https://www.idfc.org/wp-content/ uploads/2019/03/idfc_green_finance_mapping_report_2012_06-14-12.pdf

Hopf, C. (2016). Schriften zu Methodologie und Methoden qualitativer Sozialforschung. W. H. (Eds.).

Inderst, $G$, et al. (2012). Defining and measuring green investments: Implications for institutional investors asset allocations 28. OECD Working Papers on Fin., Ins. \& Priv. Pensions, Paper No. 24.

International Market Capital Association (2018). Green bond principles-voluntary process guidelines for issuing green bonds. Paris: ICMA.

Jenkins, W. (2009). In B. B. Group (Ed.), Berkshire encyclopaedia of sustainability: The spirit of sustainability, (vol. 1, 1st ed.).

Juravle, C., \& Lewis, A. (2008). Identifying impediments to SRI in Europe: A review of the practitioner and academic literature. Business Ethics: A European Review https://doi.org/10.1111/.1467\%E2\%80\%908608.2008.00536.x.

Kidney, S., et al. (2012). Climate bonds - The investment case. In W. Oulton (Ed.), Investment opportunities for a low-carbon world, (2nd ed., pp. 241-249). Environmental Finance Publications. Will-O-Climate-Bonds-Chap16-1.pdf.

Kreivi, E. (2017). Green bond market development and EIB. Luxembourg: European Investment Bank.

Kuckartz, U. (2019). Qualitative text analysis: A systematic approach. K. G., \& P. N. (eds). In Compendium for early career researchers in mathematics education, (pp. 181-197) https://doi.org/10.1007/978-3-030-15636-7_8.

Mercer (2015). Investing in a time of climate change. International finance corporation. World Bank Group. Mercer Climate Change Study 2015.

National Centers for Environmental Information. (2019). State of the climate: Global climate report for annual 2019. Retrieved January 2020, from https:// www.ncdc.noaa.gov/sotc/global/201913

Nordhaus, W. D. (1990). A general equilibrium model of policies to slow global warming. In D. Wood (Ed.), Economic models of energy and environment, proceedings of a workshop.

OECD (2017). Mobilising bond Markets for a low-Carbon Transition. In green finance and investment. Paris: OECD Publishing https://doi.org/10.1787/9789264272323-en.

Paris Agreement. (2015). United Nations. Retrieved from https:/unfccc.int/files/ essential_background/convention/application/pdf/english_paris_agreement.pdf

PRI. (2017). The SDG investment case.

PricewaterhouseCoopers. (2013). Exploring green finance incentives in China.

Rowe Price, T. (2019). MSCI (see additional disclosure); data analysis. Total return indices (net dividends).

Sandberg, J., et al. (2009). The heterogeneity of socially responsible investment. Journal of Business Ethics https://doi.org/10.1007/s10551-008-9956-0.

Saunders, E. (1993). Stock prices and wall street weather. The Journal of Finance, 83, 1337-1345.

Schwarz, B. (2015). A study on professional competence of future teacher students as an example of a study using qualitative content analysis. In A. Bikner-Ahsbahs, C. Knipping, \& N. Presmeg (Eds.), Approaches to qualitative research in mathematics education. Examples of methodology and methods, (pp. 381-399). Springer. https://doi.org/10.1007/978-94-017-9181-6_14.

Sparkes, R. (2002). Socially responsible investment: A global revolution. Wiley.

Stern, N. (2006). The economics of climate change: The Stern review. Cambridge University Press https://doi.org/10.1111/j.1728-4457.2006.00153.x. The Economics of Climate Change (doi.org).

Stoian, A., \& lorgulescu, F. (2019). Sustainable capital market. Z. M. (Eds.). In Financing sustainable development: Key challenges and prospects, (pp. 193-226).

Syzdykov, Y., \& Masse, J.-M. (2019). Emerging market green bonds report 2019: Momentum builds as nascent markets grow. Amundi Asset Management (Amundi) \& International Finance Corporation (IFC). 202005-EMGreen-BondsReport-2019.pdf (ifc.org).

Weber, O., \& Feltmate, B. (2016). Sustainable banking and finance: Managing the social and environmental impact of financial institutions. Toronto: On: University of Toronto Press.

Widyawati, L. (2019). A systematic literature review of socially responsible investment and environmental social governance metrics. Business Strategy and the Environment, 619-637 https://doi.org/10.1002/bse.2393.

World Bank Group. (2019). Data for market capitalization and green bonds issuance.

Zadek, S., \& Flynn, C. (2013). South-originating green finance: Exploring the potential. Geneva: Geneva International Finance Dialogues.

\section{Publisher's Note}

Springer Nature remains neutral with regard to jurisdictional claims in published maps and institutional affiliations.

\section{Submit your manuscript to a SpringerOpen ${ }^{\odot}$ journal and benefit from:}

- Convenient online submission

- Rigorous peer review

- Open access: articles freely available online

- High visibility within the field

- Retaining the copyright to your article

Submit your next manuscript at $\boldsymbol{\nabla}$ springeropen.com 